\title{
Topics
}

\section{Louis Silvia and Christopher T. Taylor* Gasoline and Diesel Tax Incidence: The 2003 Washington State Nickel Funding Package}

DOI 10.1515/bejeap-2015-0070

Published online June 2, 2016

\begin{abstract}
This paper considers a previously unexamined increase in excise taxes on gasoline and diesel fuel that were part of Washington State's Nickel Funding Package of 2003. We fail to reject full pass-through of the amount of the tax increase to retail prices in both products. We find no significant sensitivity of retail pass-through to station locations relative to state borders or to retail competitive conditions as measured by local station density. The expansion of hypermarkets in Washington State during the period was a confounding factor in estimating tax pass-through effects.
\end{abstract}

Keywords: tax incidence, petroleum industry, difference in difference JEL Classifications: H22, H71, L71

\section{Introduction}

This paper considers the pass-through of a previously unexamined increase in excise taxes on gasoline and diesel fuel that were part of Washington State's Nickel Funding Package of 2003. Although there is disagreement on whether pass-through is complete, earlier studies of motor fuel taxes have consistently found that consumers bear the bulk of the taxes. Previous studies agree less on why pass-through may be incomplete or may vary from one geographic area to another. Some analysts believe that incomplete pass-through is due to rising marginal costs in production or distribution; others point to less than fully competitive conduct.

\footnotetext{
*Corresponding author: Christopher T. Taylor, Federal Trade Commission, Bureau of Economics, 600 Pennsylvania Ave, NW, Washington, DC 20580, USA, E-mail: ctaylor@ftc.gov Louis Silvia, Federal Trade Commission, Bureau of Economics, 600 Pennsylvania Ave, NW, Washington, DC 20580, USA, E-mail: LSilvia@ftc.gov
} 
While most work on motor fuel tax incidence has used monthly, state-level data, we have station and product terminal level price data for 6 months preand post-tax change. The data contains a large sample of stations allowing us to test whether localized competitive conditions matter to pass-through.

An initial comparison of stations in Washington State to those in Oregon before and after the tax change suggests that pass-through is less than complete. Further analysis, however, shows that the entry and ongoing expansion of hypermarkets affects this estimate. Since the entry and expansion of hypermarkets reduce the retail mark up, not mitigating this effect biases the pass-through estimates downward. We ultimately conclude that full passthrough of the tax change cannot be rejected in both products. The entry and expansion of hypermarkets unevenly across the United States since the late 1990s is an issue for estimating pass-through generally. ${ }^{1}$ Our findings also strongly indicate no tax incidence at wholesale, a result contrary to those of some previous studies.

Section 2 reviews the literature on tax pass-through in gasoline and diesel. Section 3 offers background on the industry and the 2003 tax change. Section 4 outlines our conceptual framework and describes the data. Section 5 presents our empirical findings. Section 6 offers concluding discussion.

\section{Literature on Gasoline and Diesel Tax Incidence}

Tax pass-through is the rate of price increase to consumers per unit of tax imposed. Under perfect competition, the pass-through has an upper bound of one and is determined by the relative elasticities of supply and demand. In models of less than perfect competition, pass-through rates also depend on the curvature of demand and degree of market competitiveness (Weyl and Fabinger 2013).

Four recent studies examine pass-through of state gasoline taxes and one recent study examines gasoline and diesel taxes. Using monthly, state-level data

\footnotetext{
1 The change in the market share of hypermarkets at the state level between 1997 and 2002 is positively and significantly correlated with the change in state gasoline taxes for the same period. For markets shares of hypermarkets by state see Federal Trade Commission, Bureau of Economics, "The Petroleum Industry: Mergers, Structural Change and Antitrust Enforcement", (2004) at 248-249, available at, http://www.ftc.gov/sites/default/files/documents/reports/petro leum-industry-mergers-structural-change-and-antitrust-enforcement-report-staff-federal-trade/ 040813mergersinpetrolberpt.pdf. Hereafter referred to as the "FTC Petroleum Merger Report." State-level gasoline tax changes were calculated from multiple sources.
} 
for the 48 mainland states and the District of Columbia between 1989 and 1997, Chouinard and Perloff (2004) estimate a reduced form model with a variety of demand and cost shifters and with state and seasonal fixed effects. They find that consumers bear most of the taxes, but that consumer incidence is smaller in larger states. They attribute incidence differences to varying state-level supply elasticities. In their model, state-level supply elasticities, which reflect wholesalers' abilities to ship gasoline to lower tax states, are inversely related to a state's share of national consumption. ${ }^{2}$ Chouinard and Perloff estimate that a 1 cent per gallon ("cpg”) tax increase would raise retail prices by $0.97 \mathrm{cpg}$ in Vermont, the smallest consuming state, but only by $0.75 \mathrm{cpg}$ in California, the largest consuming state.

Barron, Blanchard and Umbeck (2004) examine a seven cpg excise tax reduction in Connecticut in July 2000. Their analysis relies on bi-weekly, station-level, retail prices and weekly, brand level, dealer tank wagon wholesale prices. ${ }^{3}$ Using a difference in difference ("DID”) approach, they compare preand post-tax-change gasoline prices in Hartford, CT with prices in other northeast metropolitan locations, assuming seasonal and state fixed effects and 6-month pre- and post-event windows. Barron, Blanchard and Umbeck find a consumer pass-through of about two-thirds. ${ }^{4}$ They conclude that rising costs at refineries absorbed most of the remaining tax decrease. They also find that retailers' revenue per gallon increased by a very small (but statistically insignificant) amount, an effect possibly reflecting rising marginal costs at retail.

Doyle and Samphantharak (2008) use daily, station-specific retail prices to analyze temporary moratoria in Indiana and Illinois of a $5 \%$ ad valorem gasoline tax in 2000. They present several specifications beginning with a simple DID comparison with neighboring states, which controls for terminal rack wholesale prices and zip-code level demographic variables are subsequently added. Applying pre- and post-tax event windows of 7 days, their results indicate that

2 A nationally measured supply elasticity should be smaller than state-level measures, and Chouinard and Perloff do find that just less than half of federal gasoline taxes are passed on to consumers. They also recognize that other factors, such as distances between states and differing gasoline formulations requirements also affect the ability of wholesalers to shift gasoline from one state to another.

3 Truck tank wagons pick up gasoline and diesel at product terminals for delivery to retail outlets. Dealer tank wagon prices are wholesale, delivered prices to retail stations. Rack prices, which we use in our analysis, refer to wholesale prices at the product terminals.

4 Barron, Blanchard and Umbeck conclude that total tax did not fall by the full amount of the excise tax reduction because of a small increase in existing ad valorem taxes owing to the increase in wholesale prices after the excise tax change. 
about $70 \%$ of the tax reduction was passed on to consumers with 80 to $100 \%$ of an increase being passed on. They also observe that pass-through occurred quickly, happening within a week of the tax change.

Doyle and Samphantharak also explore effects of local, brand-level retail concentration on tax pass-through. Some of their findings suggest that greater brand concentration is associated with higher pass-through rates, especially for tax increases. They also find some evidence of smaller pass-through, particularly for reinstatements, at affected retail locations close to the state border and some mixed evidence of price effects across state borders.

The authors also examine the effects of the tax changes on wholesale prices. They argue that the quantity changes associated with tax changes were likely to be so small that the marginal cost of wholesale gasoline should be unaffected by the taxes changes. In their view, any impact on wholesale prices might suggest that wholesale markets may not be competitive. Under this assumption that wholesale supply is (locally) perfectly elastic, they see evidence of less than full pass-through in one of three tax change regressions.

Alm, Sennoga and Skidmore (2009) analyze a panel of state-level, monthly data for the 50 U.S. states between 1984 and 1999. Estimating a reduced form model with demand and cost shifters and with state and time (monthly) fixed effects, they find a state excise tax pass-through of nearly $100 \%$ across all states, with slightly lower pass-through in more rural states. Arguing that retail markets in more urbanized states are likely to be more competitive, the authors attribute the somewhat lower pass-through rate in rural states to weaker retail competition. ${ }^{5}$ Across all states, they find that tax changes are fully passed through in the first month of the change though they observe statistically significant second month effects in medium and highly urbanized states.

Finally, Marion and Muehlegger (2011) employ a longer version of the state level, monthly data also used by Chouinard and Perloff (2004) and Alm, Sennoga and Skidmore (2009). They estimate the state and federal tax pass-thorough for both diesel and gasoline. They model the first difference in the price of diesel or gasoline as a function of the state and federal tax as well as state-level covariates and state-level fixed effects. In some specifications, year and month fixed effects are included. Marion and Muehlegger find at least full - and possibly more than full - pass-through

\footnotetext{
5 Alm, Sennoga and Skidmore observe that pass-through was greater for medium urbanized states than for highly urbanized states, a finding inconsistent with a view that highly urbanized states should have the highest pass-through, at least if demand were approximately linear. The authors also found some evidence of over shifting for medium urbanized states. Attributing incidence effects to competition differences across states requires assuming that there is no correlation between state urbanization and state-level supply elasiticities.
} 
of both federal and state diesel and gasoline taxes. Their results also suggest that pass through occurs within a month. The authors also find some support for high refinery capacity utilization leading to less than full pass-through of tax changes.

In sum, recent studies present broadly consistent results about the incidence of state motor fuel taxes. Motor fuel taxes are mostly borne by consumers. Evidence for over-shifting is limited. Tax pass-through appears to take place quickly. Quick passthrough of tax changes is consistent with Duffy-Deno (1996), EIA (1999), EIA (2003), and Lewis and Noel (2011), all of which find relatively quick pass-through of changes in wholesale gasoline prices to retail prices. Previous studies agree less whether incomplete pass-through is cost or competition related.

\section{Industry Background}

Washington State's Puget Sound was the home of five refineries in 2003. These refineries typically ran close to capacity during the first half of the 2000s. ${ }^{6}$ Washington State and Oregon consumed most of their output, though some Puget Sound gasoline and diesel went to California or was exported, particularly to nearby Canada.

The north to south flow on the Olympic and Kinder Morgan pipelines dominated the bulk distribution infrastructure of western Washington State and western Oregon. Olympic carried gasoline and diesel from the Puget Sound refineries to product terminals to the south, including those serving the relatively populated areas of Seattle, Tacoma and Olympia. Olympic connected to the Kinder Morgan pipeline at Vancouver, WA. The Kinder Morgan line ran south to serve Oregon terminals in Portland, Salem and Eugene. Olympic was generally at capacity south of Tacoma during the 2000s. Ocean barge shipments to Portland from Puget Sound supplemented shipments on Olympic. Shipments from California and foreign refineries into Portland also added to shipments from Puget Sound. ${ }^{7}$ Imports from foreign refiners (mostly gasoline) occurred primarily during higher demand summer months. ${ }^{8}$

6 Washington State Attorney General's Office, 2007-08 Gas Price Study, 2008, available at, http://www.atg.wa.gov/uploadedFiles/Another/Safeguarding_Consumers/Antitrust/Unfair_Trade_ Practices/Gas_Prices/41708gasstudy.pdf, at 16-18. Hereafter referred to as the "WA AG Gas Study". 7 WA AG Gas Study at 14-15.

8 ICF International, Review of Pipeline Utility Corridor Capacity and Distribution of Petroleum Fuels, Natural Gas and Biofuels in Southwest Washington, November 2007, at 16-17, available at http://www.efsec.wa.gov/FILES/Pipeline $\% 20$ Study/ICF\%20Washington $\% 20$ Final\%20Report $\%$ 20v4\%2012-03-07.pdf. 
The logistics of bulk distribution in the more sparsely populated eastern parts of Washington State and Oregon presented a different picture. No pipeline crosses the Cascades. Instead, river barges on the Columbia are the main source of supply. Gasoline and diesel were loaded into barges at Portland terminals or directly from ocean-going vessels landed in Portland. Pasco, WA was the primary destination for these barges. Gasoline and diesel barged to Pasco could also be injected into the Chevron pipeline for shipment northeast to Spokane.

Refineries in the Rockies also served eastern Washington and Oregon. The Yellowstone pipeline carried gasoline and diesel to Spokane and east Central Washington State from refineries in Billings, Montana. The first leg of the Chevron pipeline connected Pasco and Spokane terminals to Salt Lake City refineries. Generally, terminals in the east were located at greater distances from refineries (or points of marine landings) compared to terminals in western Washington State and western Oregon.

Washington State had nearly 3,100 gasoline retail outlets in the early 2000s. Less than half of the stations sold retail diesel. Differences in local competition, wages, land values, wholesale prices and transportation costs from terminals and other factors resulted in contemporaneous price differences across retailers. Like gasoline and diesel retailing elsewhere, price differences among stations were often significant even within a small geographic area. ${ }^{9}$

The entry of hypermarkets since the late 1990s is a notable feature of gasoline and diesel retailing in Washington State. Hypermarkets refer to retailers such as Costco, Walmart, Fred Meyer and Safeway that add fuel pumps at their retailing. Hypermarkets outlets sell five to ten times more gasoline than the typical gasoline station, have lower construction and operating costs, and typically offer lower prices. Hypermarkets sold about six percent of retail gasoline sales in the United States by late 2002. ${ }^{10}$ Hypermarket entry into Washington State as of 2002 was well above the national average, accounting for approximately 13.9 percent of gasoline sales in Washington State. Oregon hypermarket volume at the time was closer to the national average, accounting for 6.3 percent of statewide gasoline sales. ${ }^{11}$ Hypermarket sales continued to grow in subsequent years. By 2012, Hypermarkets sold over 12 percent of motor fuels in the United States. ${ }^{12}$

9 For an analysis of retail gasoline price differences Washington State between 2000 and 2007, see the WA AG Gas Study at 41-47. This study found six statistically significant variables explaining retail price differences: population per station, area wages, vehicles per station, property value, tank truck transportation costs, and percent of hypermarkets in the area.

10 FTC Petroleum Merger Report, Table 9-9 at 235-236.

11 FTC Petroleum Merger Report, Table 9-9 at 248-249.

12 Energy Analysts International, July 2012, accessed at http://www.nacsonline.com/yourbusi ness/fuelsreports/gasprices_2013/pages/statistics-and-definitions.aspx. 
Washington State's excise taxes on gasoline and diesel had been had been set at $23 \mathrm{cpg}$ since 1991. The state and federal gasoline taxes in Washington State are collected at the point of sale. The tax had lost value to inflation by 2003 falling to $18.1 \mathrm{cpg}$ in 1991 dollars. ${ }^{13}$ Recognizing a need for new capital investments in the state's transportation system, the Washington State legislature enacted the Nickel Funding Package in 2003. The Package consisted of a five cpg excise tax increase on gasoline and on-the-road diesel fuel and increases in heavy truck weight fees and motor vehicle sales taxes. The Package sought to raise $\$ 3.9$ billion dollars to pay for 158 highway transportation-related projects over ten years. ${ }^{14}$ The tax increases went into effect on July 1, 2003.

\section{Conceptual Framework and Data}

We estimate the tax pass-through with a difference-in-difference identification. We compare Washington State gasoline and diesel prices before and after the tax change with prices in nearby states (primarily Oregon). We evaluate tax incidence at wholesale and retail in separate regressions for each product. The state and federal taxes are collected at the retail level but this does not preclude possible wholesale effects of the tax. We measure short run demand and supply sensitivity. This short run would be long enough for non-capital adjustments by consumers (e.g. changed driving patterns) and sellers (e.g. changed refinery runs, changed geographic allocation of product, changed retail hours), but not long enough for significant capital-related adjustments (e.g. more fuel efficient vehicles, refinery reconfigurations, retailer entry or exit). We use 1, 3, and 6-month periods around the tax change to measure pass-through.

We believe wholesaling in the Pacific Northwest was approximately competitive. This would imply no change in wholesale prices due to the tax change. No Washington State refiner was large enough for unilateral market power to be plausible. Significant departures from marginal cost pricing would require

13 Paula Hammond and Chris Gregorie, “Washington State's Gas Tax Saga,” presentation at the National Governors Association Center for Best Practices, June 25, 2008, available at http://www.wsdot.wa.gov/NR/rdonlyres/5D8C4C3C-86B2-4BE4-B1C2-9CB1AFE36740/46936/ BestPracticesStateSummit.pdf.

14 Washington State Department of Transportation, “2003 'Nickel' Funding Package, available at http://www.wsdot.wa.gov/projects/funding/nickel/. According to Department of Energy data on gasoline and diesel sales in Washington State, the increase in excise taxes generated approximately 200 million dollars per year. Gasoline and diesel sales volumes by year by state are available at http://www.eia.gov/dnav/pet/pet_cons_prim_dcu_nus_m.htm 
coordination among the state's five refiners. In addition to the challenges in achieving and maintaining coordination among the five, shipments from California, from refineries in the Rockies and from foreign refineries would present significant obstacles to anticompetitive coordination. ${ }^{15}$

We assume that gasoline and diesel retailing is differentiated, spatially and by brand, and that departures from marginal cost pricing are limited by entry and rival repositioning. We assume that retailer-level, short-run demand elasticities vary according to the extent of localized competition raising the possibility of differing pass-through rates. ${ }^{16}$ The basic estimating equation is shown below.

$P_{i, t}=\alpha+B_{1}$ After $_{t}+B_{2}$ After $_{t}{ }^{\star}$ Treatment $_{i}+\sum_{j=1}^{n} B_{j}$ Station $(\text { rack })_{j}+\sum_{k=1}^{51} B_{k}$ Week $_{k}+\varepsilon_{i, t}$

where $P_{i, t}$ is gasoline station (rack) i's price on the day $t$. $\alpha$ is the constant. The dummy After, takes a value of one in the period after the tax increase. The interaction term After $_{t}^{\star}$ Treatment $_{i}$ is one for each rack or station in a treatment area in the period after the tax increase. The interaction variable coefficient, $B_{2}$, measures the effect of the tax increase controlling for the fixed difference in the treatment and control racks or stations before the tax change and the change in prices in the control areas in the period after the tax increase. The next two terms, Station(rack) and Week, are station (rack) and week fixed effects. The station and week dummy variables equal 1 when $i=j$ and $k=t$, respectively. The variable, $\varepsilon_{i, t}$, is the error term. In other words, we are

15 The FTC's 2006 competitive assessment of U.S refining, including West Coast refining, found no evidence of non-competitive behavior. See Federal Trade Commission, Investigation of Gasoline Price Manipulation and Post-Katrina Gasoline Price Increases, Spring 2006, available at http://www.ftc.gov/reports/060518PublicGasolinePricesInvestigationReportFinal.pdf. Moreover, the WA AG Office concluded that no illegal conduct regarding gasoline pricing in Washington was found during the period of its study, 2000-2008. See WA AG Gas Study at 2. Our assumption about market power at wholesale is the opposite of Doyle and Samphantharak's. They assume wholesale supply is perfectly elastic and attribute any significant tax event estimate in their wholesale regressions to wholesaler market power. Under our assumption, any significant (and presumably negative) tax effect on wholesale prices would be attributable to inelasticity in wholesale supply.

16 Research on gasoline demand elasticities has shown that stations with different levels of localized competition have notably different station-specific demand elasticities. For example, Barron, Umbeck and Waddell (2008) showed a 1 percent price increase led to a 3 times larger quantity effect for stations with the greatest number of local competitors relative to stations with the least number of nearby competitors. Definitively attributing presumably smaller passthrough to weak local competition requires that retailer cost elasticities are uncorrelated with the degree of local competition, however. 
controlling for common changes in the weekly price of the product across the treatment and control prices, station (rack) level fixed effects, and then measuring the price in the treatment group relative to the control group before and after the event. We adopt a null hypothesis of full pass-through at retail and zero pass-through at wholesale (rack).

Petroleum product prices are highly autocorrelated. We use the price for one day per week (Thursday) to reduce autocorrelation. ${ }^{17}$ Retrospectives of petroleum product mergers have used one of two approaches for dealing with autocorrelation. Hosken, Silvia, and Taylor (2011) recognize that OLS remains unbiased and consistent in the presence of autocorrelation and uses standard errors corrected for heteroscedasticity and autocorrelation in the underlying data.

Taylor and Hosken (2007) take an alternative approach and model the autocorrelation using the Prais-Winsten correction. This approach should be more efficient. Kreisle (2013) shows that under some statistical circumstances common to gasoline and diesel price data, modeling the autocorrelation in this way tends to perform better and comes closer to estimating the true relationship than using OLS with corrected standard errors. Here, we report results using the Prais-Winsten correction. The Prais-Winsten correction uses an estimate of the autocorrelation to transform the data. The resulting regression on the transformed data no longer has serially correlated errors. ${ }^{18}$ Results under the alternative approach, OLS with Newey-West standard errors clustered at the station level (which we do not report) are similar however. ${ }^{19}$

Price data comes from the Oil Price Information Service (OPIS). ${ }^{20}$ Rack prices consist of terminal-average daily price quotes of unbranded gasoline and diesel at terminal locations. ${ }^{21}$ We have 2003 data for twelve rack locations- seven in Washington State (Anacortes, Moses Lake, Pasco, Seattle, Spokane, Tacoma and Wilma), two in Oregon (Portland and Eugene) and one each in Montana

17 We also computed the results for alternative days and this did not qualitatively affect the results.

18 For a more complete description of the implementation of this procedure in an unbalanced panel data set see, http://www.stata.com/manuals13/xtxtregar.pdf.

19 We generated our estimates with STATA. Estimations with the Prais-Winsten correction for autocorrelation were implemented using the xtregar command. The xtreg command implemented OLS estimations with corrected standard errors clustered at the station level.

20 All gasoline data refer to conventional specification, regular octane. Octane and fuel specification distinctions are not relevant for on-the-road diesel.

21 We prefer wholesale unbranded to branded prices because unbranded is typically closer to a transactions price. Distributors who buy at posted rack prices under branded contracts may also receive various discounts, allowances and rebates from branded sellers. Our results, however, do not materially change with branded rack prices. 
(Billings), Utah (Salt Lake City) and Colorado (Denver). We use the Denver rack data as an additional check on the stability of the control racks. ${ }^{22}$

OPIS retailer price data are derived from corporate fleet card transactions and some credit card transactions. OPIS records the last transaction price charged at the station on a given day. While the gasoline and diesel pricing data from OPIS are among the best available, it is not a random sample of retail stations. Each station may also not report every day. ${ }^{23}$ We use station level fixed effects to control for changes in sample composition. ${ }^{24}$

Table 1 provides descriptive statistics for (unbranded) wholesale prices by terminal location for gasoline and diesel. Annual average rack gasoline prices by location for 2003 varied from a low of $93.9 \mathrm{cpg}$ at Denver to a high of $106.4 \mathrm{cpg}$ at Wilma. Table 1 separately groups the western and eastern terminals

Table 1: Descriptive statistics wholesale (rack) prices - 2003.

\begin{tabular}{|c|c|c|c|c|c|c|c|c|}
\hline \multirow[t]{3}{*}{ City } & \multirow{3}{*}{$\begin{array}{l}\text { Treatment/ } \\
\text { Control }\end{array}$} & \multirow{3}{*}{$\begin{array}{l}\text { State } \\
\text { East/West }\end{array}$} & \multirow{2}{*}{\multicolumn{3}{|c|}{$\begin{array}{r}\text { Gasoline } \\
\text { Unbranded Rack }\end{array}$}} & \multirow{2}{*}{\multicolumn{3}{|c|}{$\begin{array}{r}\text { Diesel } \\
\text { Unbranded Rack }\end{array}$}} \\
\hline & & & & & & & & \\
\hline & & & Obs & Mean & $\begin{array}{l}\text { Std. } \\
\text { Dev. }\end{array}$ & Obs & Mean & $\begin{array}{l}\text { Std } \\
\text { Dev. }\end{array}$ \\
\hline Billings & Control & MT & 52 & 104.8 & 8.7 & 52 & 100.1 & 9.9 \\
\hline Denver & NA & $\mathrm{CO}$ & 52 & 93.9 & 8.5 & 52 & 93.2 & 8.8 \\
\hline Salt Lake City & Control & UT & 49 & 104.0 & 8.8 & 52 & 99.0 & 10.1 \\
\hline Pasco & Treatment & WA-East & 52 & 103.8 & 13.3 & 52 & 97.2 & 12.9 \\
\hline Moses Lake & Treatment & WA-East & 52 & 103.9 & 12.2 & 52 & 99.6 & 12.1 \\
\hline Spokane & Treatment & WA-East & 52 & 104.2 & 4.0 & 52 & 99.5 & 12.1 \\
\hline Wilma & Treatment & WA-East & 44 & 106.4 & 3.0 & 44 & 98.2 & 13.8 \\
\hline Eugene & Control & OR-West & 52 & 100.6 & 3.1 & 52 & 95.0 & 13.0 \\
\hline Portland & Control & OR-West & 49 & 99.9 & 1.0 & 52 & 93.4 & 13.1 \\
\hline Anacortes & Treatment & WA-West & 52 & 98.6 & -0.1 & 52 & 91.1 & 13.2 \\
\hline Seattle & Treatment & WA-West & 52 & 100.1 & 14.3 & 52 & 92.1 & 13.3 \\
\hline Tacoma & Treatment & WA-West & 52 & 99.7 & 14.1 & 52 & 92.6 & 13.0 \\
\hline
\end{tabular}

22 Neither gasoline nor diesel excise taxes changed in the control states in 2003. The federal gasoline tax in 2003 was $18.4 \mathrm{cpg}$. The gasoline and diesel tax in Oregon in 2003 was $24 \mathrm{cpg}$. The gasoline and diesel tax in Utah was $24.5 \mathrm{cpg}$. Montana had a gasoline tax of $27 \mathrm{cpg}$ and a diesel tax of $27.5 \mathrm{cpg}$ in 2003. Colorado had a gasoline tax of $22 \mathrm{cpg}$ and a diesel tax of $20.5 \mathrm{cpg}$ in 2003. 23 For example, when we examine 1 month before and after the tax change, we have 2,199 stations in Washington and Oregon that on average have a price of gasoline for 6 of the 8 weeks. When we examine 3 months before and after the change, we have 2,476 stations that report a price on average 18 of the 25 weeks.

24 We searched the OPIS alerts and the trade press for news of refinery or pipeline outages that would have affected refined product prices in the Northwest during 2003. There were no significant outages. 
in Washington State and Oregon. Unbranded rack prices for both gasoline and diesel were lower in the west than in the east. This fact pattern is consistent with the logistical differences at wholesale supply discussed above, particularly the greater distances of eastern terminals to refineries (or points of marine landings) compared with the western terminals.

Table 2 shows descriptive statistics for gasoline and diesel retail prices for 2003, separately before and after the tax change, grouped by area averages for

Table 2: Descriptive statistics retail prices - 2003.

\begin{tabular}{|c|c|c|c|c|c|c|c|c|}
\hline \multirow[t]{2}{*}{ City } & \multirow[t]{2}{*}{ State } & \multirow[t]{2}{*}{ Months } & \multicolumn{3}{|r|}{ Gasoline } & \multicolumn{3}{|r|}{ Diesel } \\
\hline & & & Obs & Mean & Std. Dev. & Obs & Mean & Std. Dev. \\
\hline \multirow[t]{2}{*}{ Portland } & $\mathrm{OR}$ & Jan-June & 5,031 & 170.8 & 16.8 & 841 & 174.4 & 17.7 \\
\hline & & July-Dec & 4,501 & 171.6 & 14.4 & 732 & 171.3 & 10.3 \\
\hline \multirow[t]{2}{*}{ Eugene } & OR & Jan-June & 2,568 & 167.3 & 17.0 & 906 & 172.5 & 18.2 \\
\hline & & July-Dec & 2,225 & 174.4 & 13.8 & 748 & 169.4 & 8.9 \\
\hline \multirow[t]{2}{*}{ Medford } & $\mathrm{OR}$ & Jan-June & 705 & 166.0 & 16.5 & 210 & 169.7 & 17.5 \\
\hline & & July-Dec & 678 & 177.2 & 12.5 & 177 & 162.5 & 13.4 \\
\hline \multirow[t]{2}{*}{ Salem } & OR & Jan-June & 979 & 164.6 & 17.1 & 154 & 171.2 & 20.2 \\
\hline & & July-Dec & 865 & 167.9 & 14.4 & 116 & 166.0 & 11.6 \\
\hline \multirow[t]{2}{*}{ Rest of OR } & $\mathrm{OR}$ & Jan-June & 5,153 & 168.5 & 16.0 & 1,939 & 172.9 & 18.0 \\
\hline & & July-Dec & 4,909 & 175.1 & 12.6 & 1,891 & 169.4 & 11.1 \\
\hline \multirow[t]{2}{*}{ All of OR } & $\mathrm{OR}$ & Jan-June & 14,278 & 168.8 & 16.6 & 4,010 & 172.9 & 18.1 \\
\hline & & July-Dec & 13,027 & 173.5 & 13.8 & 3,631 & 169.3 & 10.9 \\
\hline \multirow[t]{2}{*}{ Vancover } & WA & Jan-June & 1,400 & 160.3 & 16.1 & 285 & 167.6 & 15.7 \\
\hline & & July-Dec & 1,474 & 164.7 & 14.1 & 283 & 167.6 & 8.8 \\
\hline \multirow[t]{2}{*}{ Seattle } & WA & Jan-June & 8,230 & 168.6 & 17.3 & 1,894 & 174.1 & 18.9 \\
\hline & & July-Dec & 7,870 & 169.7 & 15.2 & 1,641 & 171.6 & 10.2 \\
\hline \multirow[t]{2}{*}{ Tacoma } & WA & Jan-June & 3,244 & 159.9 & 17.5 & 660 & 172.4 & 18.8 \\
\hline & & July-Dec & 3,242 & 163.2 & 14.7 & 600 & 168.9 & 10.2 \\
\hline \multirow[t]{2}{*}{ Everet } & WA & Jan-June & 3,228 & 163.5 & 16.6 & 675 & 171.7 & 19.1 \\
\hline & & July-Dec & 3,196 & 168.6 & 15.3 & 678 & 169.6 & 10.4 \\
\hline \multirow[t]{2}{*}{ Spokane } & WA & Jan-June & 2,571 & 159.3 & 14.5 & 419 & 172.9 & 16.3 \\
\hline & & July-Dec & 2,457 & 166.8 & 10.0 & 383 & 171.4 & 6.0 \\
\hline \multirow[t]{2}{*}{ Olympia } & WA & Jan-June & 1,041 & 158.2 & 16.9 & 298 & 164.9 & 17.0 \\
\hline & & July-Dec & 1,192 & 166.3 & 13.9 & 322 & 167.1 & 7.9 \\
\hline \multirow[t]{2}{*}{ Bellingham } & WA & Jan-June & 880 & 162.3 & 18.0 & 183 & 168.7 & 18.8 \\
\hline & & July-Dec & 927 & 171.7 & 13.9 & 161 & 165.1 & 8.0 \\
\hline \multirow[t]{2}{*}{ Pasco } & WA & Jan-June & 345 & 163.1 & 11.6 & 94 & 169.2 & 15.5 \\
\hline & & July-Dec & 335 & 169.0 & 9.8 & 117 & 168.3 & 8.1 \\
\hline \multirow[t]{2}{*}{ Rest of WA } & WA & Jan-June & 9,257 & 162.9 & 15.2 & 2,653 & 168.5 & 17.1 \\
\hline & & July-Dec & 9,455 & 171.3 & 12.7 & 2,575 & 169.1 & 8.3 \\
\hline \multirow[t]{2}{*}{ All of WA } & WA & Jan-June & 30,196 & 163.6 & 16.6 & 7,161 & 170.7 & 18.0 \\
\hline & & July-Dec & 30,148 & 168.8 & 14.1 & 6,760 & 169.6 & 9.2 \\
\hline
\end{tabular}


major cities, plus an average for the area outside these cities. Overall, state averages for Oregon and Washington State are also shown. Area average retail prices within the two states differed by as much as $5 \mathrm{cpg}$. Washington State's retail prices were generally lower than Oregon's, especially for gasoline. The overall average change in Washington and Oregon prices before and after the tax change show little if any effect of the tax change. The average price of gasoline increased by approximately five cents in both states between the first and last 6 months of the year. The average price of diesel decreased approximately four cpg in Oregon and one cpg in Washington. These averages do not control for the fact that the panel of stations is not balanced. ${ }^{25}$

Area averages mask the considerable contemporaneous price variation among retailers within areas. For example, in the week before the tax increase, retail gasoline prices in the Seattle area ranged from $144 \mathrm{cpg}$ to $190 \mathrm{cpg}$, with a range in diesel of $160 \mathrm{cpg}$ to $180 \mathrm{cpg}$. Similarly, at that time gasoline prices in Portland at the time ranged between $150 \mathrm{cpg}$ to $180 \mathrm{cpg}$, with diesel prices ranging between $160 \mathrm{cpg}$ and $180 \mathrm{cpg}$. Although the differences between the highest and lowest retailer in an area might be $20 \mathrm{cpg}$ or greater, most retailers charged prices much closer to the area average.

\section{Empirical Results}

Inspection of the raw gasoline and diesel retail price data for Washington State overall suggest a nearly immediate impact of the tax change. ${ }^{26}$ Figure 1 shows daily average gasoline and diesel prices in Washington State, less the price in Oregon, controlling for station level fixed effects, in the month before and after the tax change on July 1 , 2003. The average price of gasoline for July 1 was about $4 \mathrm{cpg}$ more than the previous day, with smaller increases over the next several days. The average price of diesel for July 1 was $3 \mathrm{cpg}$ more than the previous day. Diesel prices move from being about $4 \mathrm{cpg}$ cheaper in Oregon before the tax change to about $1 \mathrm{cpg}$ more in Oregon in the second week after the tax change.

Our pass-through analysis begins at wholesale. We find no evidence that the tax change significantly affected Washington State rack prices as a whole for

25 In all of 2003, there are 2,597 stations reporting a price of gasoline in Washington and Oregon. On average, stations report just under 33 of the 52 weeks (Thursdays) in the data. However, some stations only report 1 week while others report every week. The number of diesel observations follows a similar pattern.

26 Inspection of the raw gasoline and diesel wholesale data shows no obvious immediate impact. 


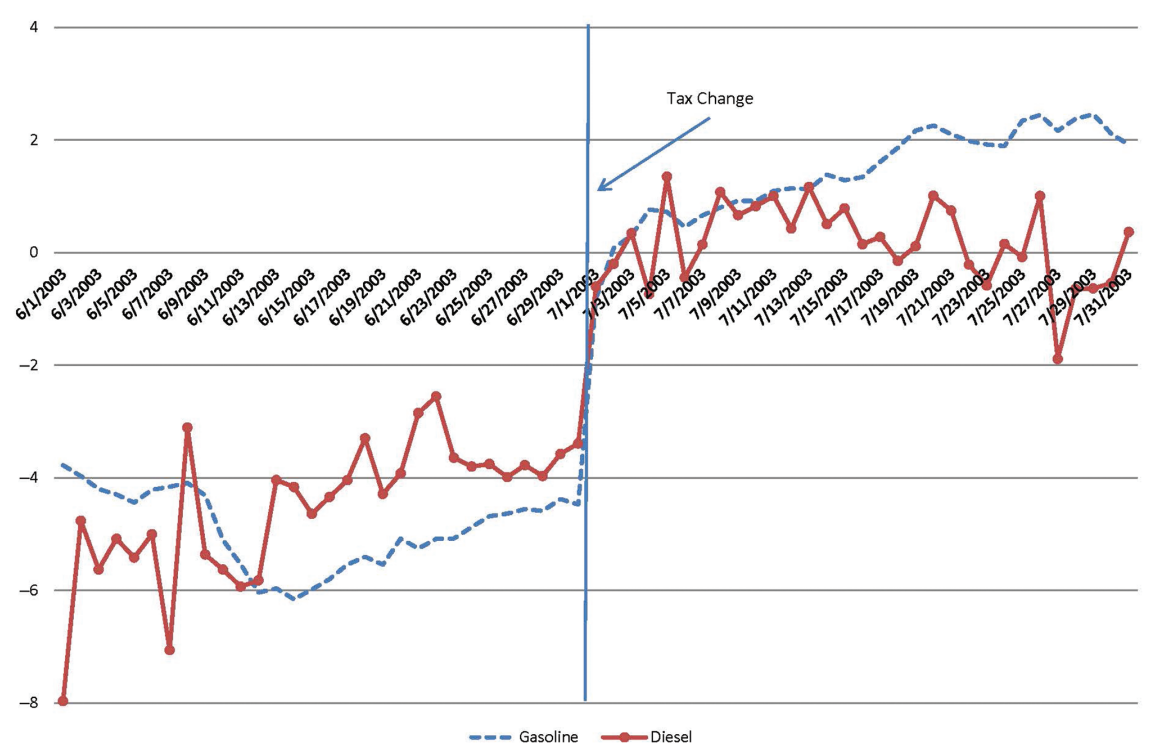

Figure 1: Difference in Washington and Oregon Daily Average Retail Price June 1-July 31, 2003. Note: This is the difference, Seattle less the rest of Washington, in the average station price by month controlling for station level fixed effects.

either gasoline or diesel fuel. Consistent with Barron, Blanchard and Umbeck, we estimate the tax pass-through using 6-month pre- and post-tax change windows. We also provide estimates using 1-month and 3-month windows. The first two rows of Table 3 show DID estimates in gasoline and diesel for symmetric pre-event and post-event windows, utilizing all Washington State treatment and non-Washington State controls. ${ }^{27}$ Negative point estimates would be

27 For this comparison, we used all the racks listed on Table 1 with the exception of Denver. We checked whether geographic reallocation of supply by refiners and other wholesalers in reaction to the tax increase might bias our estimates downward. For example, Oregon wholesale prices might fall if Puget Sound refiners responded to a tax-related reduction in wholesale demand in their home market by redirecting some refinery output to Oregon terminals. Conceivably, there might be a similar depressing effect in Billings and Salt Lake City, as refiners in those locations shipped somewhat less into Washington State. Accordingly, we compared wholesale prices in these control areas with wholesale prices in Denver, where marginal supply originates at refineries in the midcontinent and the Texas Panhandle and thus Denver prices were extremely unlikely to be affected by the Washington State tax change. Comparison of pre- and post-tax differentials for Denver/Portland, Denver/Billings and Denver/Salt Lake City showed no statistically significant change. 
Table 3: Wholesale (rack) gasoline and diesel pass-through.

\begin{tabular}{llrrrr}
\hline Sample & Pre/Post & Gasoline & Obs & Diesel & Obs \\
\hline Table 1 Treatment/control racks & 1 Month & -0.64 & 88 & -0.24 & 88 \\
& & $(2.20)$ & & $(1.65)$ & \\
Table 1 Treatment/control racks & 3 Month & 2.25 & 269 & 1.58 & 275 \\
& & $(2.45)$ & & $(1.50)$ & \\
Table 1 Treatment/control racks & 6 Month & 0.13 & 547 & 0.87 & 553 \\
& & $(1.63)$ & & $(1.25)$ & \\
Table 1 East/west WA racks & 1 Month & -2.56 & 64 & -1.97 & 64 \\
Table 1 East/west WA racks & \multirow{2}{*}{ 3 Month } & $0.14)$ & & $(1.44)$ & \\
& & $(1.84)$ & & -1.62 & 200 \\
Table 1 East/west WA racks & 6 Month & 0.67 & 397 & -0.43 & 400 \\
& & $(1.20)$ & & $(0.99)$ & \\
\hline
\end{tabular}

Notes: Estimates of $B_{2}$ in eq. [1] H0: $B_{2}=0$, no pass-through. Daily once a week data. Control variables include week and rack fixed effects. Standard errors in parentheses.

expected if the state's gasoline or diesel were inelastically supplied at wholesale. However, half of the estimated coefficients are positive and more importantly none of estimates come close to being significantly different from zero.

Owing to their more remote location from refineries and key logistical supply points, it is possible that eastern Washington State terminals, Pasco, Moses Lake, Spokane and Wilma, were less elastically supplied than those in the west, Anacortes, Seattle, and Tacoma. If so, wholesale prices in the east could fall relative to those in the west after the tax increase. We find no evidence of such an effect, as the last three rows of Table 3 shows results evaluating whether the tax increase affected the wholesale prices in eastern Washington State relative to those in western Washington State. The list of the racks included in the east and west groupings are shown on Table 1 . No parameter estimates are significantly different from zero and a number of the point estimates are very close to zero as well.

These wholesale findings overall suggest that full pass-through to retail might be expected. Table 4 shows estimates for eq. [1] for gasoline and diesel based on the full sample of Washington and Oregon retailers for symmetric pre/ post windows. These estimates, however, indicate that pass-through to consumers was incomplete. Diesel estimates are somewhat less precise owing to the smaller sample size compared to gasoline.

As is well known, DID estimation critically assumes a constant price differential between the treatment and control markets, except for the change caused 
Table 4: Station specific retail gasoline and diesel pricing.

\begin{tabular}{|c|c|c|c|c|c|}
\hline Sample & Pre/Post & Gasoline & Obs & Diesel & Obs \\
\hline All Stations WA/OR & 1 Month & $\begin{array}{l}4.37^{\star \star} \\
(0.28)\end{array}$ & 13,651 & $\begin{array}{l}0.97^{\star \star} \\
(0.72)\end{array}$ & 3,220 \\
\hline All Stations WA/OR & 3 Month & $\begin{array}{l}3.62^{\star \star} \\
(0.20)\end{array}$ & 43,826 & $\begin{array}{l}3.94^{\star \star} \\
(0.40)\end{array}$ & 10,807 \\
\hline All Stations WA/OR & 6 Month & $\begin{array}{l}3.14^{\star \star} \\
(0.15)\end{array}$ & 85,003 & $\begin{array}{l}3.26^{\star \star} \\
(0.35)\end{array}$ & 20,325 \\
\hline
\end{tabular}

Notes: Estimates of B2 in eq. [1] H0: B2 = 5, full pass-through. Daily once a week data. Control variables include week and station fixed effects. Standard errors in parentheses.

**Reject full pass-through at $95 \%$ confidence level.

by the event. ${ }^{28}$ It appears that the entry and expansion of hypermarkets not only affected retail prices in Washington State relative to Oregon over the period, but also affected relative retail prices within Washington State. ${ }^{29}$ The mere existence of hypermarkets in differing degrees in treatment and control markets would not frustrate identification if their price effects were time-invariant, but this was not the case. ${ }^{30}$

Washington State publishes data on underground fuel tanks. These data show the ongoing hypermarket entry in 2002 and 2003. ${ }^{31}$ The leading urban locations of Seattle, Spokane, and Vancouver had most of this hypermarket entry. In particular, more than a third of the state's hypermarkets were in the Seattle Metropolitan Statistical Area (MSA) and more than half were in the Seattle Combined Statistical Area ("CSA"). ${ }^{32}$

A comparison of retail gasoline prices in the Seattle CSA to those of the rest of the state in 2002 and 2003 illustrates the impact of hypermarket entry. Figure 2 shows the

28 Using data from 2002, we estimated the effect of a phantom event in the second half of 2002, July through December, using the same treatment and control markets. There was no statistically significant effect of this phantom event using all the stations for Washington and Oregon. 29 Contemporaneous newspaper articles report the entry of hypermarkets in Seattle and Washington State and that retail margins were decreasing. See Puget Sound Business Journal http://www.bizjournals.com/seattle/stories/2003/03/24/story5.html?page = all

30 We re-estimated the 2002 placebo regression using just the hypermarket areas of Washington as the treatment. We found that prices were three-quarters of a cent lower during the second half of 2002 in hypermarket areas relative to the Oregon control prices over the same period.

31 Tank data on hypermarket entry in Oregon is less helpful since they do not include the date of entry. The Oregon tank data does show that there are fewer hypermarkets than in Washington and over half of all hypermarkets stations are in the greater Portland area.

32 The Seattle MSA consists of the city of Seattle, King County, Snohomish County, and Pierce County. The Seattle CSA is the MSA plus Kitsap, Thurston, Skagit, Island, and Mason Counties. 


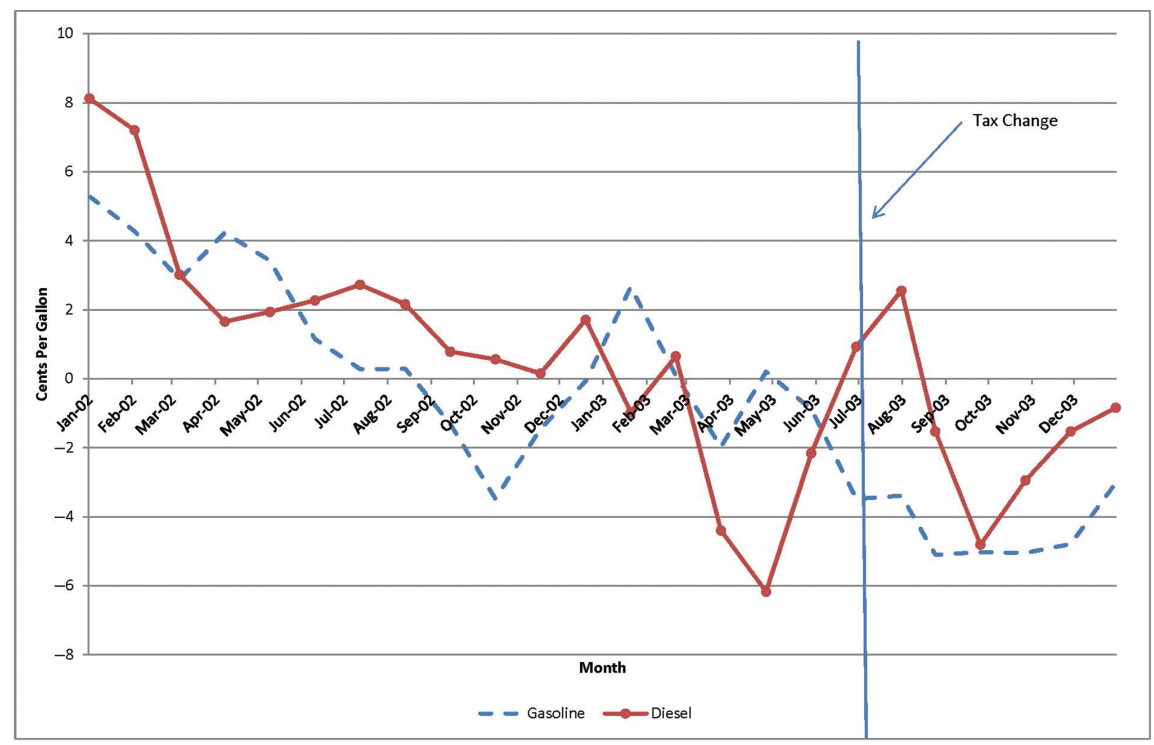

Figure 2: Difference in Seattle and rest of Washington state monthly average retail price 2002-2003.

Note: This is the difference, Seattle less the rest of Washington, in the average station price by month controlling for station level fixed effects.

monthly price difference in gasoline and diesel between the Seattle CSA and the rest of Washington, controlling for station level fixed effects. Seattle CSA prices fell relative to the rest of the state over the period. Seattle gasoline was more expensive by two to six cpg in early 2002 but by the end of the year, gasoline in Seattle was several cents cheaper than gasoline in the rest of the state. The same seasonal pattern occurred for gasoline prices in 2003, but the average annual difference between Seattle and the rest of the state is roughly a penny per gallon lower compared to 2002. Diesel prices in Figure 2 follow a similar trend to gasoline prices.

To mitigate the confounding effects from hypermarket entry, we re-estimate eq. [1] removing from the sample those stations that are within 10 miles of a hypermarket in Washington and all gasoline stations in Portland, OR. ${ }^{33}$ In a "hypermarket free" sample, shown in Table 5, point estimates are higher

33 We identified all hypermarkets in the Washington State underground tank database in 2003 and then identified all gasoline stations that were within 10 driving miles of the hypermarket stations. If a station was within 10 miles of a hypermarket at any time during 2003, it was removed from the sample. 
Table 5: Station specific retail gasoline and diesel pricing - non-hypermarket areas.

\begin{tabular}{lccccr}
\hline Sample & Pre/Post & Gasoline & Obs & Diesel & Obs \\
\hline Non-Hypermarket Areas (WA/OR) & 1 Month & $\begin{array}{c}5.47 \\
(0.43)\end{array}$ & 6,174 & 2.73 & 1,699 \\
& & & $(1.62)$ & \\
Non-hypermarket areas (WA/OR) & 3 Month & 4.53 & 20,084 & 4.82 & 5,631 \\
& & $(0.26)$ & & $(0.55)$ & \\
Non-hypermarket areas (WA/OR) & 6 Month & 4.55 & 39,178 & 3.94 & 10,838 \\
& & $(0.22)$ & & $(0.56)$ & \\
\hline
\end{tabular}

Notes: Estimates of B2 in eq. [1] H0: B2 = 5, full pass-through. Daily once a week data. Control variables include week and station fixed effects. Standard errors in parentheses. **Reject full pass-through at $95 \%$ confidence level.

compared to the full sample. A full, five cpg pass-through to consumers cannot be rejected for either product. ${ }^{34}$

Table 6 shows the same pass-through regression with the stations in the hypermarket areas in Washington as the treatment and stations in Portland, $\mathrm{OR}$ as the control. When comparing these hypermarket areas, we cannot reject full pass-through for five of the six regressions. The point estimates of passthrough are generally lower and the standard errors are somewhat higher than the results in Table 5, but the hypermarket areas have a pass-through much closer to one than the blended sample of hypermarket and non-hypermarket

Table 6: Station specific retail gasoline and diesel pricing - hypermarket areas.

\begin{tabular}{lccccr}
\hline Sample & Pre/Post & Gasoline & Obs & Diesel & Obs \\
\hline Hypermarket areas (WA/OR) & 1 Month & 4.28 & 7,477 & 2.18 & 1,521 \\
& & $(0.43)$ & & $(2.62)$ & \\
Hypermarket areas (WA/OR) & 3 Month & 4.45 & 23,742 & 4.00 & 5,176 \\
& & $(0.31)$ & & $(0.76)$ & \\
Hypermarket areas (WA/OR) & \multirow{2}{*}{ 6 Month } & $4.47^{\star \star}$ & 45,825 & 3.94 & 9,487 \\
& & $(0.23)$ & & $(0.70)$ & \\
\hline
\end{tabular}

Notes: Estimates of B2 in eq. [1] H0 : B2 =5, full pass-through. Daily once a week data. Control variables include week and station fixed effects. Standard errors in parentheses. ** Reject Full Pass-Through at $95 \%$ confidence level.

34 In a previous version of the paper, we removed all the stations in the Seattle CSA, Spokane, Cowlitz and Clark counties and the Portland MSA in Oregon. The majority of hypermarkets in Oregon are in the Portland MSA. The estimated pass-through was very similar. 
areas of shown in Table $4 .{ }^{35}$ The results in Table 6 suggest that the increased competition provided by hypermarkets is shrinking retail markups in both states for stations near the hypermarkets.

Retail gasoline prices depend, in part, on local competition. If competitive differences result in differing retailer-level demand elasticities, we might expect some differences in tax pass-through across retailers. We first consider whether pass-through is sensitive to retailers' locations relative to state borders. We test whether the difference in prices at Washington State stations located "close to" important border crossings vary pre- and post-tax change relative to stations elsewhere in the state. Close to border stations, presumably, should post smaller price increases than stations elsewhere in the state. We estimate eq. [1] using stations close to the Washington border as the treatments and the controls are the stations in the rest of the state. We only estimate the 3- and 6-month windows given the number of observations. We limit the treatment and control areas to those without significant hypermarket entry, with the exception of the Idaho border. ${ }^{36}$

We find little evidence of border effects for Washington retailers in either gasoline or diesel. Table 7 shows the close-to-border results for Canada, Idaho and Oregon; estimates refer to the difference in pass-through for near border stations compared to other stations in Washington State (excluding areas impacted by hypermarkets). While point estimates for gasoline and diesel for the Oregon border are negative, many other estimates have the wrong sign. In every case, we cannot reject the null of equal pass-through.

We do find evidence of border effects for Oregon stations in both gasoline and diesel. Similar to the above estimation, we estimated eq. [1] with data from Oregon. The treatment stations are near the border and the control stations are in the rest of the state less the hypermarket areas. As reported in Table 8, gasoline and diesel prices increased significantly at Oregon retailers located close to the Washington State border in 6-month window specifications and one of the 3-month window specifications. The magnitude of the 3-month diesel

35 We also estimated pass-thorough for stations in the Seattle CMSA and Spokane MSA that were greater than 10 miles from a hypermarket using stations in Oregon, less Portland, as the controls. This estimation showed full pass-through in five of the six regressions. These results suggest that the presence of a nearby hypermarket affects pass-through not that some other difference in the greater hypermarket areas is affecting pass-through.

36 The larger number of observations in the Idaho regressions are due to including Spokane, a hypermarket area. Those Spokane zip codes adjacent to the border are included in the treatment and the rest of the Spokane MSA is included in the control. Without the Spokane treatment stations, there would not have been enough observations to estimate the 3-month regressions due to the small number of treatment stations. 
Table 7: Station retail gasoline and diesel price-Washington state near borders.

\begin{tabular}{llcccr}
\hline Sample & Pre/Post & Gasoline & Obs & Diesel & Obs \\
\hline WA stations near CND vs & 3 Month & 1.46 & 8,693 & 2.57 & 2,349 \\
Rest of WA stations & & $(1.76)$ & & $(4.81)$ & \\
WA stations near CND vs & 6 Month & 0.93 & 17,387 & -3.04 & 4,615 \\
Rest of WA stations & & $(2.27)$ & & $(4.06)$ & \\
WA stations near ID vs & 3 Month & 1.09 & 11,116 & -3.73 & 2,720 \\
Rest of WA stations & & $(1.64)$ & & $(5.97)$ & \\
WA stations near ID vs & 6 Month & 0.91 & 22,282 & -2.97 & 5,367 \\
Rest of WA stations & & $(1.24)$ & & $(5.44)$ & \\
WA Stations Near OR vs & 3 Month & -2.31 & 8,693 & -1.96 & 2,349 \\
Rest of WA stations & & $(2.46)$ & & $(2.52)$ & \\
WA stations near OR vs & 6 Month & -0.65 & 17,387 & -0.71 & 4,615 \\
Rest of WA stations & & $(1.86)$ & & $(2.52)$ & \\
\hline
\end{tabular}

Notes: Estimates of B2 in eq. [1] H0 : B2 =0, equal pass-through. Daily once a week data. Control variables include week and station fixed effects. Standard errors in parentheses.

Table 8: Station retail gasoline and diesel price-Oregon near border.

\begin{tabular}{|c|c|c|c|c|c|}
\hline Sample & Pre/Post & Gasoline & Obs & Diesel & Obs \\
\hline $\begin{array}{l}\text { OR stations near WA border vs } \\
\text { Rest of OR stations }\end{array}$ & 3 Month & $\begin{array}{c}0.43 \\
(1.03)\end{array}$ & 13,752 & $\begin{array}{l}10.86^{* *} \\
(3.23)\end{array}$ & 3,739 \\
\hline $\begin{array}{l}\text { OR stations near WA border vs } \\
\text { Rest of OR stations }\end{array}$ & 6 Month & $\begin{array}{l}2.91 * \star \\
(0.65)\end{array}$ & 26,489 & $\begin{array}{l}3.10^{\star \star} \\
(0.96)\end{array}$ & 7,198 \\
\hline $\begin{array}{l}\text { OR stations next closet to WA vs } \\
\text { Rest of OR stations }\end{array}$ & 3 Month & $\begin{array}{c}1.89 \\
(1.38)\end{array}$ & 13,277 & $\begin{array}{c}2.81 \\
(4.46)\end{array}$ & 3,563 \\
\hline $\begin{array}{l}\text { OR stations next closet to WA vs } \\
\text { Rest of OR stations }\end{array}$ & 6 Month & $\begin{array}{c}0.93 \\
(0.89)\end{array}$ & 25,568 & $\begin{array}{c}1.28 \\
(3.71)\end{array}$ & 6,872 \\
\hline
\end{tabular}

Notes: Estimates of B2 in eq. [1] H0: B2 = 0, equal pass-through. Daily once a week data. Control variables include week and station fixed effects. Standard errors in parentheses.

effect is large relative to the tax change. These effects dissipate, however, when we compare Oregon retailers located somewhat further away from the Washington State border (stations in the next closest zip codes) to all Oregon stations to the south as the next two rows of results show.

Finally, we examine if localized competition at retail matters to passthrough. Using the census of gasoline stations from the Washington State underground tank registry, we identified the number of other stations within 
one mile of each gasoline station in our sample. We divided the stations into four categories: stations without a competitor within a mile, stations with 1 or 2 competitors within a mile, stations with 3 or 4 competitors within a mile and stations with greater than 4 competitors within a mile. The four categories contained 17.5, 20.1, 26.4 and 36 percent of the observations in order from least to highest number of competitors.

Tables 9 shows the estimated pass-through for the four categories of stations for gasoline and diesel prices for both 3- and 6-month windows. We re-estimate eq. [1] using all the stations in Washington and Oregon more than 10 miles from a hypermarket, but with a different pass-through parameter for each of the four categories of station. The point estimates for the gasoline tax pass-through for each category are generally close to $5 \mathrm{cpg}$, while point estimates for diesel are more variable across station categories and in some cases close to $7 \mathrm{cpg}$. However, only when comparing one of the point estimates for diesel relative to another, category four relative to category one, is the difference statistically significant. In no case can full pass-through be rejected.

Table 9: Station retail gasoline pass-through by number of competitors.

\begin{tabular}{lcccccr}
\hline Sample & Pre/Post & Group & Gasoline & Obs & Diesel & Obs \\
\hline Non-hypermarket & 3 month & 1 & 5.02 & 23,822 & 6.99 & 6,289 \\
areas (WA/OR) & & & $(0.44)$ & & $(1.20)$ & \\
& & 2 & 4.69 & & 6.57 & \\
& & & $(0.40)$ & & $(1.22)$ & \\
& & & 4.33 & & 4.94 & \\
& & & $(0.36)$ & & $(1.08)$ & \\
& & 4 & 4.67 & & 3.62 & \\
Non-hypermarket & 6 month & 1 & 5.06 & 46,275 & 6.47 & 12,006 \\
areas (WA/OR) & & & $(0.41)$ & & $(1.21)$ & \\
& & 2 & 4.64 & & 5.92 & \\
& & & $(0.37)$ & & $(1.24)$ & \\
& & & 4.30 & & 4.57 & \\
& & & $(0.34)$ & & $3.11)$ & \\
& & 4 & 4.59 & & $(0.89)$ & \\
\hline
\end{tabular}

Notes: Estimates B2 in eq. [1] H0: B2 =5, full pass-through. Daily once a week data. Control variables include week and station fixed effects. Standard errors in parentheses. 


\section{Discussion}

West Coast refiners were generally operating close to capacity in the early 2000s, and the tax increase occurred right at the peak of summertime demand. Under these circumstances, the tax increase might be expected to reduce wholesale prices owing to diminishing returns.

On the other hand, the reduction in quantity demanded due to the tax increase was small and probably unlikely to have much of an impact upon marginal supply costs once geographic reallocation of product is considered. Washington State daily average gasoline consumption was approximately 170 thousand barrels per day ("MBD") in 2003. Full pass-through to consumers of the Nickel Package tax would increase pump prices by about three percent. Assuming a gasoline demand elasticity of -0.2 , this price increase would decrease Washington State demand by about $1 \mathrm{MBD}$. By comparison, total gasoline production in 2003 for the five Puget Sound refineries was approximately $292 \mathrm{MBD}$, and other refiners also supplied the Pacific Northwest to some extent. Any reduced demand for gasoline and diesel in Washington State could most likely be accommodated by slightly reduced imports into the Pacific Northwest, perhaps in conjunction with slightly increased exports by Puget Sound refiners.

Our main retail result is that we fail to reject full tax pass-through in gasoline and diesel. These findings are consistent with those in most previous studies of gasoline. The similarity of diesel to gasoline pass-through of is not surprising - the demands for both products are highly inelastic and the costs of producing and distributing the two products are similar.

Full pass-through is also consistent with our expectation about retail-level short run cost elasticities within the quantity range relevant to the tax change. Assuming a statewide reduction in demand of about $1 \mathrm{MBD}$, a significant impact upon marginal costs at the retail level seems unlikely. A reduction of $1 \mathrm{MBD}$ of gasoline is equivalent to 42,000 gallons per day. Washington State had about 3,100 gas stations in the early 2000s. Given a daily statewide reduction of 42,000 gallons, the average gas station would see a reduction in sales of just fewer than 14 gallons per day, or about less than one vehicle visit per day. Such a small quantity reduction also seems unlikely to affect significantly costs at the margin of tank-wagon deliveries from product terminals.

Consequently, any differences in pass-through at the station level in our framework of differentiated retail competition would be driven by differences in station level demand elasticities. We examined for near border effects based on the notion that stations close to the borders would be more constrained in increasing prices than others in the state. We find no significant differences in pass-through for retailers located close to the Canadian, Idaho and Oregon borders compared to other Washington retailers. 
The absence of a pass-through differential near the Canadian border is not surprising. Gasoline prices on the Canadian side (the greater Vancouver area) averaged more than $40 \mathrm{cpg}$ greater than nearby Washington State stations in the first half 2003, while Canadian diesel was about $25 \mathrm{cpg}$ greater than that available just across the border in Washington State. Canadian stations were very likely a weak constraint on the pass-through by close to border Washington stations. Pre-tax price differentials are less persuasive as explanation for an absence of differential pass-through effects for Washington stations on the Oregon and Idaho borders since the price differences were much smaller than the differences with Canada. ${ }^{37}$

Conceivably the absence of pass-through differentials for Washington border stations might be attributed to the rural nature of these border areas, such as low demand density or limited road connections to neighboring states, factors which would limit the diversion of demand. Yet arbitrage across at least the Washington/Oregon border appeared robust enough to increase significantly gasoline and diesel prices at Oregon stations adjacent to the Washington border. This effect in Oregon, however, dissipated with distance from the border. ${ }^{38}$

We found no strong evidence that localized competitive conditions matter to pass-through. Full-pass through cannot be rejected for any of the categories of stations. There is only very limited evidence that the estimated pass-through was different by competitive category.

The expansion of Washington State hypermarkets complicated identifying pass-through. We dealt with this problem by eliminating observations near hypermarkets. When only stations that were greater than 10 miles from a hypermarket were used, pass-through of the tax was complete. In addition, when we compare the hypermarket areas of Washington and Oregon we cannot reject full pass-through.

The complications arising from hypermarket expansion in Washington State illustrate a more general issue in assessing tax pass-through in gasoline and diesel in the United States. Perhaps no other part of the petroleum industry has

\footnotetext{
37 While first half 2003 prices for Washington State border stations averaged $7.5 \mathrm{cpg}$ below nearby Oregon border stations, diesel was cheaper on the Oregon side by $0.5 \mathrm{cpg}$. We have no station-specific price data for Idaho, but we note that first half 2003 gasoline prices at Washington Stations near the Idaho border were about a penny cheaper than the state-level average Idaho average, while diesel was cheaper in Idaho by about $5 \mathrm{cpg}$.

38 Ideally, we would be able to test the ability to arbitrage across borders by examining population and commuting patterns, but this data is not readily available.
} 
changed as much in recent decades as gasoline and diesel retailing. The number of services stations has fallen and volume per outlet has increased. Vertical integration between refining and retailing has declined. In addition to hypermarkets, new high volume formats such as convenience store chains, such as Sheetz, RaceTrac and Wawa, have increasingly challenged the traditional, corner service station. The extent and pace of this evolution has varied across states, within states and in the late 1990s and 2000s is correlated with statelevel tax changes. Researchers of tax pass-through in U.S. motor fuels should pay careful attention to these potentially confounding effects particularly when estimates are based on sizeable panels.

Acknowledgments: We thank Jeffrey Fischer, Daniel Hosken, Nicholas Kreisle and anonymous referees for helpful comments and Elisabeth Murphy and Gregory Dowd for research assistance. The views expressed are those of the authors and do not necessarily represent those of the U.S. Federal Trade Commission or any individual Commissioner.

\section{References}

Alm, J., E. Sennoga, and M. Skidmore. 2009. "Perfect Competition, Urbanization, and Tax Incidence in the Retail Gasoline Market." Economic Inquiry 47 (1):118-34.

Barron, J., K. Blanchard, and J. Umbeck. 2004. "An Economic Analysis of a Change in an Excise Tax." Journal of Economic Education 35 (2):184-96.

Barron, J., J. Umbeck, and G. Waddell. 2008. "Consumer and Competitor Reactions: Evidence From a Field Experiment." International Journal of Industrial Organization 26:517-31.

Chouinard, H., and J. Perloff. 2004. "Incidence of Federal and State Gasoline Taxes." Economics Letters 83 (1):55-60.

Doyle, J., and K. Samphantharak. 2008. " $\$ 2.00$ Gas! Studying the Effects of a Gas Tax Moratorium." Journal of Public Economics 92 (3-4):869-84.

Duffy-Deno, K.. 1996. "Retail Price Asymmetries in Local Gasoline Markets." Energy Economics 18 (1-2):81-92.

EIA. 1999. "Price Changes in the Gasoline Market: Are Midwestern Gasoline Prices Downward Sticky?" Accessed December 6, 2013. http://www.eia.gov/petroleum/archive/0626.pdf.

EIA. 2003. "Gasoline Price Pass-Through.” Accessed December 6, 2013. http://www.eia.gov/ petroleum/archive/gasolinepass.htm.

Hosken, D., L. Silvia, and C. Taylor. 2011. "Does Concentration Matter: Measurement of Petroleum Merger Price Effects.” American Economic Review Papers and Proceedings 101 (3):45-50.

Kreisle, N. 2013. “Merger Policy at the Margin: Western Refining's Acquisition of Giant Industries." Federal Trade Commission Bureau of Economics Working Paper.

Lewis, M., and M. Noel. 2011. "The Speed of Gasoline Price Response in Markets with and Without Edgeworth Cycles." Review of Economics and Statistics 93 (2):672-82. 
Marion, J., and E. Muehlegger. 2011. "Fuel Tax Incidence and Supply Conditions.” Journal of Public Economics 95:1202-12.

Taylor, C., and D. Hosken. 2007. "The Economic Effects of the Marathon-Ashland Joint Venture: The Importance of Industry Supply Shocks and Vertical Market Structure." Journal of Industrial Economics 55 (2):419-51.

Weyl, G., and M. Fabinger. 2013. "Pass-Through as an Economic Tool: Principles of Incidence Under Imperfect Competition.” Journal of Political Economy 121 (3):528-83. 